\title{
TRADISI PEMAKAMAN \\ DALAM MASYARAKAT SUMBA TIMUR SEBAGAI PENDEKATAN KONTEKSTUAL
}

\author{
Yuliana Lu
}

\section{PENDAHULUAN}

Masyarakat Sumba Timur mempunyai sistem kepercayaan yang diwariskan dari para leluhurnya. Di Sumba Timur pada hari tertentu selalu diadakan upacara pemujaan nenek moyang mereka. Nenek moyang mereka itu dipersonifikasikan dalam berbagai bentuk atau sosok sakti tertentu yang salah satunya bersemayam di pohon beringin.

Masyarakat Sumba Timur sangat menghormati leluhur mereka, karena mereka percaya bahwa leluhur mereka adalah orang-orang yang pertama kali membuka tanah Sumba Timur. Leluhur orang Sumba Timur disebut marapu yang sudah dianggap sebagai dewa. ${ }^{1}$ Fungsi kepercayaan bahwa puncak-puncak gunung diyakini sebagai tempat dewa-dewi roh-roh halus atau kekuatan gaib. Gunung-gunung tertentu dari beberapa wilayah tertentu bersifat keramat atau dikeramatkan dan ditetapkan sebagai pusat kegiatan adat kepercayaan marapu, yang lain ditetapkan sebagai pusat perhimpunan arwah orang mati dari kabihu-kabihu yang terkait atau parai marapu atau disebut juga negeri arwah orang mati. ${ }^{2}$

Masyarakat Sumba Timur terbagi atas tiga tingkatan yaitu: pertama, Raja atau Tuan (mirri). Kedua, masyarakat menengah atau orang biasa (kabihu), ketiga, hamba (ata). Dalam kalangan raja atau dalam bahasa daerahnya mirri, mempunyai harta yang banyak, mempunyai hewan, tanah yang luas, dan juga mempunyai banyak hamba. Hamba-hamba ini bertugas melayani tuannya.

Dalam tradisi orang Sumba Timur, khususnya dalam kalangan raja ataupun dalam kalangan rakyat biasa, pemakaman orang mati adalah hal yang sangat penting. Karena menurut kepercayaan mereka, jika orang yang sudah mati diadati atau dihormati, maka orang yang mati itu akan memberi berkat kepada orang yang masih hidup.

Kematian dalam masyarakat Sumba Timur digolongkan atas pertama meti maringu, artinya mati dingin atau wajar atas kehendak Sang Khalik, yang disebabkan karena penyakit atau lanjut usia; dan yang kedua meti mbanahu artinya mati panas, karena mendapat musibah.

Menurut kepercayaan orang Sumba Timur, yang percaya kepada marapu, penyebab kematian sebagai berikut: pertama, dewa atau marapu yang dipuja marah karena pelanggaran tertentu. Kedua karena kutukan. Ketiga karena roh-roh halus,

${ }^{1}$ Nggodu Tunggul, Aspek Budaya Sumba Timur Timur, (Kupang: Depertemen P dan K, 2001),

${ }^{2}$ Suh Sung Min, Injil dan Penyembahan Nenek Moyang, (Yogyakarta: Medio Presindo, 2001), 
kekuatan gaib di alam raya, akibat pelanggaran atau kelalaian manusia, dan yang keempat karena adanya suanggi. ${ }^{3}$

Menurut kepercayaan orang Sumba Timur, pada saat seseorang nafasnya putus, dan selama mayat yang ada di rumah belum dikebumikan, arwahnya diyakini masih pulang balik dari rumah duka ke dalam parai marapu atau tempat tinggalnya para dewa dan marapu dan juga tempat kehidupan orang yang sudah mati. Kepercayaan ini diiringi dengan gong duka yang disebut dengan tundu kalakungu, setiap pagi hari dan petang disertai iringan doa pelepasan ke parai marapu, dengan nasi sajian.

Dalam kalangan raja atau bangsawan biasanya mayat dipetikan bertahuntahun, dalam bahasa darahnya kabangu. Selama dalam upacara pemakaman itu, ada upacara pemotongan hewan, antara lain kerbau atau kuda sebagai korban. Daging hewan yang sudah dipotong ini tidak boleh diambil atau dimakan, karena menurut kepercayaan mereka kerbau atau kuda ini merupakan pendamping roh orang yang sudah meninggal itu, menuju ke alam baka. Jadi kerbau atau kuda ini akan dibiarkan sampai dagingnya membusuk atau dimakan anjing. ${ }^{4}$

Dalam tradisi Sumba Timur, orang yang sudah mati dengan cara wajar atau mati dingin tidak langsung dikuburkan tetapi mayat ini akan dibiarkan sampai bertahun-tahun, dimasukkan ke dalam kamar khusus, atau mayat itu didudukkan, diikat, dan dibungkus dengan berlapis-lapis kain adat, setelah itu disimpan dalam rumah adat. Bagi para bangsawan, sementara mayat belum dimakamkan bertahuntahun, sanak saudaranya yang masih hidup akan bekerja dan mengumpulkan uang untuk biaya pemakanan sang bangsawan yang meninggal itu. Upacara pemakaman di kalangan orang Sumba Timur lebih ramai dari dari upacara-upacara lainnya. Biasanya upacara ini akan dilangsungkan selama satu minggu atau lebih. Dan saudara orang yang meninggal ini harus mengundang sanak saudara mereka, baik keluarga dekat atau pun keluarga jauh, kenalan mereka ataupun kenalan dari orang yang mati ini. Suku ini sangat dikuasai oleh tradisi, termasuk tradisi pemakaman. Itu berarti hampir setiap orang dalam suku ini meninggal tanpa percaya kepada Tuhan Yesus.

\section{BENTUK PELAKSANAAN PEMAKAMAN}

Bentuk pelaksanaan pemakaman dalam masyarakat Sumba Timur pada dasarnya sama, kalau pun ada perbedaan, hanya beda tipis, yaitu dilihat dari status si mati dan kemampuan penyelenggaraan upacara, serta berdasarkan cara mati dan umur pada waktu mati. Semakin keluarga si mati mempunyai kemampuan finansiil, maka akan semakin mewah dan mahal upacara pemakamannya.

\footnotetext{
${ }^{3}$ Nggodu Tunggul, Aspek Budaya ..., 122

${ }^{4}$ Umbu Peku Jawang, Mozaik Pariwisata Nusa Tenggara Timur, ( Kupang: Dinas Pariwisata, 1987), 91
} 


\section{$\underline{\text { Pelaksanaan Pemakaman untuk Raja (maramba) }}$}

Kematian seorang raja atau maramba sangat menarik perhatian karena banyaknya tahapan-tahapan ritual yang harus dilaksanakan. Kematian seorang maramba tidak boleh diumumkan selama belum dilakukan suatu upacara yang disebut pampengingu (menyadarkan), atau upacara untuk memastikan apakah ia sungguh-sungguh telah mati. Seorang ratu (imam) akan dipanggil untuk melakukan sembayang kepada dewa dan para leluhur, kemudian memanggil nama resmi empat sampai delapan kali. ${ }^{5}$ Apabila tidak ada reaksi dari si mati, maka ia dinyatakan benar-benar telah meninggal, sehingga gong dengan irama duka dibunyikan sebagai tanda kedukaan, yang diikuti dengan pemotongan seekor kuda jantan yang bermakna sebagai tunggangan si mati menghadap sang pencipta, karena kalau tidak melakukan hal tersebut dianggap arwah si mati masih berkeliaran ke sana ke mari. Dalam upacara ini sang ratu menyembelih seekor ayam untuk melihat di dalam hati tersebut apakah orang ini sudah benar-benar mati atau belum. Kemudian diberitahukan kepada tetangga dan keluarga terdekat, dan mayat ini akan segera ditangisi oleh keluarga dan tetangga. Jenazah dimandikan yang dihadiri khusus oleh keluarga inti, lalu dikenakan pakaian yang bagus dan atribut yang melambangkan status kebangsawanan, seolah-olah akan mengadakan perjalanan yang jauh. Dalam upacara memandikan mayat ini akan dipotong kuda milik si mati, tidak boleh milik keluarga karena dipercayai kalau memotong hewan milik keluarga atau orang lain, nanti akan dirampas oleh yang punya hewan di negeri arwah orang mati atau parai marapu.

Setelah mayat dimandikan akan dibungkus dengan berlapis-lapis kain adat. Kaki dan tangan ditekuk sama seperti posisi janin dalam rahim. Pada mulut diberi mamuli yang terbuat dari emas, tangan dan kaki diberi manik-manik yang disebut anahida (muti salak). Bila yang meninggal wanita, diberi anting-anting pada telinganya. Selimut dan tempat air minum diletakkan pada samping sebelah kirinya. Jenazah didudukkan pada balai-balai kecil yang disandarkan pada tiang rumah. Dalam upacara membungkus si mati dengan kain adat dilakukan pemotongan hewan (kerbau atau babi) sebagai bekal bagi si mati. Imam mempersembahkan seekor ayam atau babi dan sirih pinang untuk menyambut dan menjamu arwah leluhur yang datang menjemput si mati yang diiringi dengan pemukulan gong dengan irama patalamba. Kemudian jenazah dimasukkan ke dalam sebuah peti kayu atau kulit kerbau, disandarkan pada tiang penyembahan dengan menghadap ke pintu sebelah kanan rumah. Seekor kuda dipotong sebagai persembahan, dan imam meminta kepada marapu agar diberi kekuatan dan perlindungan untuk melaksanakan seluruh rangkaian upacara kematian dan penguburan sebagaimana ditentukan oleh leluhur. Kemudian keluarga inti melakukan musyawarah awal untuk membicarakan segala persiapan upacara selanjutnya.

Selama jenazah belum dikuburkan, harus terus dijaga siang dan malam oleh keluarga, terutama kaum wanita dan para hamba dari si mati. Mereka duduk di sekitar jenazah untuk melayani si mati dengan makanan, minuman dan sirih pinang.

${ }^{5}$ Teriakan pemanggilan nama si mati diteriaki empat kali untuk kabihu atau rang merdeka dan delapan kali untuk raja atau marimba, upacara ini dilakukan karena dipercaya bahwa arwah si mati mesih berkeliaran ke sana ke mari, teriakan penggilan arwah si mati bertujuan agar ia kembali ke rumah. 
Setiap pemberian makanan, minuman dan sirih pinang selalu diawali dengan pemukulan gong dengan irama patalamba untuk memanggil arwah si mati menikmati makanan dan minuman yang disajikan oleh hambanya. Setelah selesai, gong dengan irama halakung kembali dipukul untuk mengantar kembali arwah si mati. Setiap malam dipotong kuda atau kerbau agar si mati dibawa ke parai marapu. Para tamu yang datang melayat juga dilayani sirih pinang, makanan dan minuman.

Dua minggu menjelang upacara penguburan, keluarga bersama kaum kerabat melakukan pawalla (mete), dan pada upacara pemakaman maramba selalu dinyanyikan syair-syair adat yang diikuti dengan tarian duka (renja pai) yang dilakukan oleh laki-laki dan perempuan yang mengisahkan perjalanan hidup si mati bersama leluhur yang telah meninggal. Orang yang bertugas menyanyikan lagu-lagu tersebut adalah orang-orang yang terpilih yang diawali dengan sembayang. Selama mereka menjalankan tugas itu, tidak boleh terjadi pergantian dengan orang lain, dan lagu yang dinyanyikan tidak boleh salah. Bila terjadi kesalahan yang tidak disengaja, setelah melakukan tugas tersebut pelakunya harus mengadakan sembayang untuk meminta ampun kepada marapu. Bila hal ini tidak dilakukan, bisa mendatangkan bencana bagi pelaku.

\section{$\underline{\text { Pelaksanaan Pemakaman untuk Hamba }}$}

Dalam pelaksanaan pemakaman untuk hamba, upacara pemakamannya hampir sama dengan golongan pejabat adat (kabihu), terutama yang mempunyai kedudukan dan pengabdian di dalam golongan raja (maramba). Binatang yang disembelih seekor saja atau seadanya, kalau pun tidak ada, tidak dipersoalkan, tergantung dari materi yang telah disiapkan oleh keluarga. Jika dalam golongan ini telah disiapkan dana dan materi yang cukup, maka upacara pemakamannya dilaksanakan cukup meriah.

\section{$\underline{\text { Pelaksanaan Pemakaman untuk Orang Merdeka }}$}

Pelaksanaan pemakaman untuk orang merdeka (kabihu) tidaklah sebesar dan semegah pemakaman dalam golongan raja (maramba). Upacara penguburan seorang kabihu bergantung pada posisi orang itu dalam masyarakat, apakah ia seorang kabihu bokulu atau kabihu kudu. Kalau ia seorang kabihu bokulu, selain diratapi dan gong dipukul, juga diadakan papanggangu dua orang atau sekurang-kurangnya satu orang. Kalau ia kabihu kudu, maka ia hanya diratapi saja. Pengiring jemazah dapat dilakukan oleh kaum keluarganya saja, dan binatang atau hewan korban yang disembelih cukup empat ekor saja, upacara penguburannya pun hanya 3 sampai 4 hari saja. 


\section{PEMAKAMAN}

\section{Dua Jenis Cara Mati}

Bentuk pelaksanaan pemakaman, berdasarkan cara mati dalam masyarakat Sumba Timur, dibedakan atas dua macam yaitu mati dingin (meti maringu) yang disebabkan oleh penyakit atau lanjut usia dan mati panas (meti mbanahu) yaitu kematian dengan cara yang tidak lazim.

\section{Mati Dingin}

Mati dingin atau meti maringu adalah mati wajar, karena merupakan kehendak sang pencipta umat manusia. Untuk masyarakat Sumba Timur yang mati dengan cara seperti ini akan diadakan upacara-upacara seperti biasa, mayatnya dapat disimpan di dalam rumah, dan juga dapat disimpan lama.

\section{Mati Panas}

Mati panas atau meti mbanahu adalah kematian yang luar biasa artinya suatu kematian disebabkan karena kecelakaan, terbunuh, bunuh diri, jatuh dari pohon, ditangkap buaya, disambar petir, gantung diri dan lain-lain. Orang yang meninggal dengan musibah di atas, tidak boleh dimasukkan di dalam rumah, tetapi langsung dikuburkan di tempat lain atau di luar lokasi pekuburan keluarga atau pekuburan umum. Mayatnya juga tidak boleh disimpan lama. Setelah beberapa tahun, baru diadakan acara hukum adat kematian resmi, tulang belulang digali kembali baru dipindahkan di kuburan umum atau kuburan keluarga. ${ }^{6}$

\section{Persiapan Pemakaman}

Masyarakat Sumba Timur percaya, bahwa upacara penguburan sangat menentukan perjalanan arwah orang yang meninggal untuk tiba di paring marapu dan bersekutu bersama nenek moyangnya. Upacara penguburan sangat penting dalam kehidupan orang Sumba Timur dan membutuhkan biaya yang sangat besar, oleh karena itu keluarga terkait dari yang meninggal harus benar-benar mempersiapkan pelaksanaan upacara tersebut. Persiapan yang dilakukan tidak saja berupa materi tetapi juga non materi, misalnya berbagai pertikaian atau perselisihan di antara keluarga terkait harus diselesaikan terlebih dahulu, bila tidak diselesaikan maka arwah dari si mati tidak akan tenang di alam baka. Peristiwa kematian harus diikuti dengan berbagai upacara agar yang meninggal mendapat tempat yang layak di seberang kuburan. Relasi kekerabatan di antara klen-klen terkait harus berada dalam suasana harmonis. Bila tidak, maka upacara penguburan tidak dapat dilaksanakan.

\footnotetext{
${ }^{6}$ Nggodu Tunggul, Aspek Kebudayaan Sumba Timur..., 122
} 
Persiapan dari keluarga orang yang meninggal, sebelum upacara pemakaman adalah dana dan materi, para undangan dan juga pengadaan batu kubur. Pada saat orang meninggal sampai dengan penguburan, keluarga harus mengadakan beberapa kali upacara untuk marapu dan para leluhur.

\section{Undangan Pemakaman}

Ketika persiapan upacara penguburan sudah selesai dan menjelang hari pemakaman keluarga si mati akan mengundang kenalan dan keluarga yang terkait yang jauh dan dekat untuk datang ke acara pemakaman. Keluarga dan kenalan akan diberitahu dengan cara adat. Keluarga orang yang meninggal akan mengutus seorang utusan untuk mengundang dan utusan ini disebut wunang (juru bicara). Keluarga yang diundang menyambut petugas undangan atau wunang dengan pembantaian berupa hewan yaitu ayam, babi, kerbau, dagingnya sebagian dimakan di tempat atau makan bersama yang sisa seluruhnya dibawa oleh wunang ke rumah duka. Wunang akan membawa mamuli mas dan rantai tembaga (lolu amah) kepada pihak pemberi perempuan (yera). Pihak year akan membalas dengan menikam seekor babi dan memberikan kain atau sarung. Sedangkan utusan kepada pihak pengambil istri (layia), membawa kain atau sarung dan dibalas dengan memberi mamuli mas dan rantai tembaga. Balasan tersebut menandakan bahwa mereka akan hadir dalam upacara penguburan.

\section{Dana dan Materi}

Sistem pengebumian masyarakat Sumba Timur terkait dengan masalah dana dan materi. Jika dana belum cukup disiapkan oleh keluarga si mati, maka pemakaman itu belum bisa dilaksanakan. Materi pembawaan disesuaikan dengan tingkat adat perkawinan yang telah diperlakukan di masa silam. Keluarga si mati harus dengan matang menyiapkan segala kebutuhan yang dibutuhkan selama acara upacara pemakaman. Selain menyiapkan hewan korban, setiap malam keluarga juga harus menyiapkan hewan seperti babi, sapi, untuk makanan para undangan. Lauk pauk daging yang sisa tidak diperkenankan untuk penyajian makanan malam berikutnya. Jadi setiap malam harus dipotong ternak untuk menjamu para tamu. Sayur mayur tidak dikenal untuk tamu dan adat kematian.

\section{Pengadaan Batu Kubur}

Batu kubur juga sangat penting dalam upacara pemakaman. Batu kubur ini biasanya diambil dari atas gunung dan ditarik ke kampung ke tempat pemakaman. Dalam penarikan batu kubur ini, diadakan upacara dengan pemotongan hewan korban. Batu kubur ini ditarik oleh sekitar 1000 sampai 2000 orang. Di setiap perhentian dalam penarikan batu kubur, harus dipotong hewan untuk menjadi makanan para penarik. Sambil menarik batu kubur para penarik harus menyanyikan 
lagu dalam bahasa daerah yang dipimpin oleh seorang ratu (imam). Upacara penarikan batu kubur ini mengeluarkan biaya yang sangat besar dan juga hewanhewan untuk dijadikan korban dan makanan para penarik.

\section{Upacara Pemakaman}

Hari penguburan dipahami sebagai awal perjalanan arwah si mati ke parai ngumarapu. Upacara penguburan dilaksanakan pada sore hari, dan seluruh upacara harus selesai sebelum matahari terbenam. Jenazah dikuburkan di dalam batu kubur, yang terletak di tengah-tengah kampung. Batu kubur dipandang sebagai rumah yang tak pernah lapuk. Sebagaimana orang yang hidup tinggal di rumah yang layak, demikian juga orang yang mati harus ditempatkan dalam 'rumah' yang layak pula, yaitu batu kubur. Batu kubur tersebut harus diletakkan di depan rumah dan di tengah kampung karena orang yang meninggal dianggap masih bagian dari kampung.

\section{Sebelum Pemakaman}

Menjelang pelaksanaan pemakaman, dipilihlah hamba-hamba dari orang yang meninggal itu, yang akan menjalankan tugas papanggangu (pengawal/pengiring jenazah). Pemilihan papanggangu dilakukan melalui sembayang khusus. Para papanggangu ini adalah hamba setia dari si mati. Papangganggu terdiri dari empat orang dengan tugasnya masing-masing (dua orang laki-laki dan dua orang perempuan). Adapun tugas dari papanggangu itu adalah: orang pertama penunggang kuda, seorang pria yang akan menunggang kuda orang yang meninggal. Kuda itu dihiasi, antara lain perhiasan emas, kalung bulu ayam, rumbai-rumbai dari kain sutera dan kain tenun. Pengawal ini merupakan pengawal utama yang sekaligus merupakan penjelmaan dari orang yang meninggal. Orang yang kedua adalah seorang pria yang akan membawa seekor ayam jantan, yang akan menangis dekat kubur sebagai simbol penyucian. Orang yang ketiga yang menjunjung topi, yaitu seorang wanita yang memakai tudung. Orang yang keempat, seorang wanita yang akan membawa sirih pinang yang terbuat dari muti atau logam.

Dalam menjalankan tugasnya, para pengawal mendapat layanan yang istimewa, seolah-olah melayani orang yang meninggal itu sendiri. Mereka diberi pakaian yang indah-indah yang melambangkan status kebangsawanan tuannya. Selain sebagai pengawal atau pengiring, papanggangu juga berfungsi sebagai media antara orang hidup, di mana dalam keadaan itu pula orang-orang yang hidup menyampaikan kehendak keinginannya kepada orang yang sudah mati.

Sebelum papangganga ini menjadi pengiring orang yang meninggal, mereka akan disucikan terlebih dahulu melalui suatu upacara, lalu mereka didandani dengan pakaian adat terbaik dan lengkap dengan perhiasan. Ketika dalam keadaan kesurupan maka terjadilah komunikasi antara orang yang meninggal dengan keluarganya. Di situlah permintaan-permintaan terakhir dapat disampaikan. 


\section{Pada Saat Pemakaman}

Pada hari pemakaman, rombongan yang tiba pada hari itu disambut dan dilayani seperti undangan yang telah tiba terlebih dahulu. Pada saat acara pemakaman, ratu (imam) memimpin doa kepada marapu seiring dengan itu jenazah ditangisi. Setelah itu diadakanlah upacara pahadangu (membangun), yaitu upacara 'membangunkan' si mati untuk 'mendengarkan' dan 'mengikuti' tutur kata ratu (imam) mengenai rute perjalanan si mati menghadap sang pencipta, dimulai dari bumi sampai ke langit kedelapan.

Dalam upacara ini sang ratu (imam) tidak diperkenankan untuk salah mengucapkan atau salah menunjukkan jalan bagi si mati karena akan mempengaruhi perjalanan si mati menghadap sang pencipta. Sebelum jenazah diturunkan dari balaibalai atas, maka ratu (imam) akan mempersembahkan korban seekor ayam atau babi, kemudian hati dari salah satu hewan tersebut dimasak untuk makanan si mati, sehingga ia tiba di paraingumarapu tidak dalam keadaan lapar. Makanan ini sekaligus merupakan makanan terakhir bagi si mati. Setelah diletakkan di depan mayat, lalu dibuang ke arah matahari terbenam. Selain itu juga imam meminta kepada marapu agar memberi petunjuk jalan kepada si mati agar ia tiba di parai marapu dengan selamat. Peti jenazah diusung oleh pemuda dari golongan bangsawan, menuju liang lahat diiringi bunyi gong (tudung halaku). Di depannya adalah imam, disusul para pengawal (papanggangu) yang berjalan sambil menangis bahkan sampai pingsan. Pengusung jenazah harus berjalan cepat ketika menuju kuburan untuk menghindari gangguan roh jahat yang mungkin datang menghalangi upacara tersebut. Sebelum jenazah diturunkan ke liang lahat, jenazah dengan papangangu bersama keluarga dan kerabat melalui arah kiri mengintari liang lahat empat atau delapan kali. Dan khusus bagi pengawal yang berada di atas kuda, naik ke atas kubur melalui tangga dan duduk bersila di bawah payung. Perhiasan yang dikenakannya lebih lengkap dibandingkan tiga pengawal lainnya. Setelah menjalani tugas sebagai papanggangu, ia akan naik status.

Keluarga dan para undangan juga diberi kesempatan untuk meratapi si mati dan memberikan kenang-kenangan berupa mamuli mas terutama dari pihak layia untuk terakhir kalinya bagi si mati, kenang-kenangan tersebut dimasukkan ke dalam liang lahat bersamaan dengan dimasukkan jenazah si mati. Jenazah dibaringkan dalam liang kuburan, selimut sarung yang tiba kemudian dirobek-robek lalu dimasukkan ke dalam liang kuburan. Selimut sarung yang diselubungkan di atas keranda mayat dapat ditarik atau diambil oleh wanita yang statusnya anawini sebagai kenangan acara penguburan, dan dapat pula diimbangi dengan pemberian mamuli atau lulu amah. Kuburan ditutup, di atas kuburan/batu penutup atas diletakkan sirih pinang, petugas yang mengangkat mayat dari wadah usungan ke liang kuburan, mencuci tangan memperebutkan air kelapa muda di atas penutup kuburan. Setelah batu kubur ditutup, dilakukan pemotongan ternak yang disebut dangang, terdiri dari dua ekor kerbau dan dua ekor kuda. Daging dari ternak ini tidak dimakan, karena dianggap merupakan bawaan dari si mati ke alam baka. Setelah kuburan ditutup, para pengawal kembali ke rumah adat dan duduk di atas balai-balai bagian atas. Di halaman rumah dibantai dua ekor kerbau dewasa yang tanduknya panjang, seekor jantan dan seekor betina. Di samping rumah dipotong kuda (njara dangangu), daging 
kuda ditinggalkan menjadi makanan anjing. Para tamu dijamu makanan dan minuman serta diberi daging (kameti) yang dipotong khusus untuk dibawa pulang.

\section{Setelah Pemakaman}

Pada hari keempat setelah upacara pemakaman, diadakan upacara padita waimata (menaikkan air mata). Upacara ini dilaksanakan di kuburan si mati. Sampai hari itu keluarga yang berkabung tetap tinggal di rumah perkabungan dan setiap pagi dan petang hari mengantarkan sirih pinang serta bau-bauan di atas kuburan yang meninggal dan setiap malam terus diberi sajian kepada arwah yang meninggal. Setelah selesai memberikan sesajen kepada arwah si mati, papanggangu turun dari rumah adat dan pergi menyimpan sirih pinang ke atas kuburan. Hari keempat, dilaksanakan memandikan papanggangu di sungai. Setelah selesai mandi, papanggangu harus kembali ke kampung dengan tidak melewati jalan waktu pergi. Maksudnya adalah papanggangu sudah disucikan dari tugasnya. Setelah upacara memandikan papanggangu, dilakukan upacara membuka ikat kepala papanggangu, membuka segala perhiasan mereka, kecuali pakaian dan perhiasan yang diberi kepada mereka. Untuk upacara ini dipotong seekor kerbau. Pada hari itu juga dilaksanakan upacara berhenti berkabung. Imam memohon kepada marapu agar mengampuni seluruh kesalahan yang mungkin terjadi sejak kematian hingga penguburan. Setelah itu dilakukan upacara pamaringuuma (mendinginkan rumah). Semua orang dalam kampung tersebut kena percikan air. Rumah yang 'panas' menjadi 'dingin' kembali. Menurut kepercayaan orang Sumba Timur, selama jenazah belum dikuburkan, rumah dalam keadaan 'panas' sehingga perlu 'didinginkan kembali'. Upacara pamaringuuma ini juga bermaksud untuk mengusir roh jahat dari dalam kampung sehingga seluruh warga kampung terbebas dari bahaya dan dapat kembali melaksanakan aktifitas seperti sediakala.

Upacara terakhir adalah paludungu (menyampaikan arwah si mati ke paraingu marapu). Upacara ini dilakukan tiga atau empat tahun kemudian. Berdasarkan kepercayaan marapu, bila upacara ini belum dilaksanakan, maka arwah si mati akan tetap tinggal di luar kampung saja. Imam mempersembahkan korban ayam dan babi atau kerbau kepada marapu, untuk memohon agar arwah si mati berjalan terus dan jangan kembali lagi. Dengan selesainya acara ini, arwah si mati telah menjadi marapu atau dewa seperti leluhur yang lainnya. Setelah itu tempat sirih pinang si mati dibuang sebagai simbol pemutusan hubungan dengan arwah si mati. Dengan demikian selesailah seluruh rangkain acara upacara pemakaman. 
Missio Ecclesiae, 5(2), Oktober 2016, 134-152

\section{PEMAHAMAN ALKITAB TENTANG KEMATIAN DAN UPAYA PENDEKATAN KONTEKSTUAL}

Paul G. Hiebert memperkenalkan metode kontekstualisasi yang ia sebut sebagai critical contextualization. Teori ini terbagi tiga bagian yang berisi bagaimana sikap pemberita Injil terhadap kebudayaan. Yang pertama penolakan terhadap budaya setempat, menolak semua bentuk kebudayaan pendengar karena kebudayaan dianggap suatu dosa. Dalam hal ini berita Injil menjadi sangat asing. Kedua penerimaan yang tidak kritis. Akibat pelayanan ini adalah sinkritisme. Ketiga berhubungan dengan kebudayaan/critical contextualization. Mengumpulkan data kebudayaan, mempelajari kebenaran Firman Tuhan tentang data-data ini, mengevaluasi data dengan Firman Tuhan dan menciptakan suatu kegiatan Kristen (berita) yang baru atau berkontekstualisasi. ${ }^{7}$ Dalam upacara-upacara pemakaman yang sering dilakukan oleh masyarakat Sumba Timur, ada beberapa hal yang sangat bertentangan dengan iman Kristen. Misalnya cara memandikan mayat, memberi makan mayat, menjaga mayat dan masa-masa berkabung.

\section{Memandikan Mayat}

Bagi masyarakat Sumba Timur apabila ada yang meninggal mayatnya harus dimandikan. Mandi atau memandikan mayat mempunyai pengertian membersihkan tubuh dengan air, dengan cara disiram atau merendam dalam air. Tujuan memandikan ini adalah untuk membersihkan tubuhnya dan juga supaya roh mayat tersebut tidak menjelma menjadi hantu dan akhirnya menjadi hantu dan datang kembali.

Dalam kitab Ayub 10:21, mengatakan ia tidak kembali lagi sebab pada waktu ia mati ia pergi ke rumahnya yang kekal. Volkhard Scheuneman menyatakan: Roh orang mati mutlak dalam kekuasaan Allah dan Kristusnya. Barangsiapa memanggil Allah, mencampuri hak dan kuasa Allah, dan Tuhan akan melenyapkan dia dari tengah-tengah bangsanya (bd. Im. 20:6). Tak mungkin roh orang mati patuh terhadap perintah manusia, dukun atau iblis. Yang datang bukannya arwah orang mati, melainkan roh jahat dan iblis yang menyamar sebagai orang mati. ${ }^{8}$ Sehingga dengan demikian bahwa roh-roh orang mati berada mutlak di tangan Kristus. Karena Dialah yang berhak atas semuanya itu. Pada waktu Yesus membangkitkan anak Yairus yang sudah mati, maka kembalilah roh anak itu, dan seketika itu juga ia bangkit dan berdiri (Luk. 8:55). Demikian juga pada waktu Yesus membangkitkan Lazarus, Ia berseru dengan suara keras "lazarus marilah keluar" (Yoh. 11:1-44), maka Lazarus segera bangkit dan datang kepada Yesus lalu Tuhan Yesus menyuruh orang-orang untuk membuka kain kafan yang ada di tubuh Lazarus. Dengan demikian hanya Yesus Kristus sebagai Mesias berhak memanggil roh orang mati kembali atau membangkitkan manusia, itu bukan dalam kuasa manusia, bukan pula dalam kuasa

\footnotetext{
${ }^{7}$ Paul G. Hiebert, Antropological Insights for Missionaries, (Grand Rapids: Baker Book Hause, 1985), 171-192

${ }^{8}$ Volkhard Scheuneman, Apa Kata Alkitab Tentang Dunia Orang Mati, ( Batu: Literatur YPPII, 1981), 22
} 
seorang dukun, oleh karena manusia tidak berkuasa atas nyawa seseorang (Pkh. $8: 8)^{9}$

\section{Memberi Makan Mayat}

Memberi makan kepada mayat merupakan keharusan yang sangat penting. Hal ini dikarenakan apabila mereka tidak melakukannya maka roh orang mati tersebut akan mendatangkan sakit penyakit dan malapetaka lainnya. Sebenarnya pada saat manusia itu meninggal dan mayatnya diberi makanan, maka sia-sialah segala sajian dan persembahan makanan yang diberikan kepadanya, karena yang mengambil untung dari sajian itu hanyalah roh-roh dunia atau jin-jin (Im. 17:7; Kol. $2: 8 ; 2: 20$ ). Dalam pemahaman masyarakat Sumba Timur, memberi bekal atau makanan orang yang sudah mati adalah sebagai bekal dalam perjalanan menuju alam baka. Tetapi Alkitab menjelaskan bahwa pada saat seseorang meninggal, saat itu juga roh orang mati itu sudah sampai pada tempat tujuannya (bd. Luk. 23:43). Peralihan antar dunia orang hidup ke dunia orang mati terjadi dalam sekejab mata. Dan lagi arwah tak mungkin dibekali dengan hal-hal duniawi dan jasmani. Alkitab berkata bahwa manusia tidak membawa sesuatu ke dalam dunia dan tidak membawa apa-apa ke luar (I Tim.6:7; Ayub 1:21a).

\section{Pandangan Iman Kristen Terhadap Tradisi Pemakaman}

Dalam bagian ini penulis akan menjelaskan pandangan iman Kristen terhadap tradisi pemakaman, yang mencakup pembahasan tentang pandangan iman Kristen terhadap kematian, upacara pemakaman dan konsep hidup sesudah mati.

\section{Kematian}

Menurut Alkitab, kematian merupakan ungkapan tentang terputusnya hubungan antara Allah dan manusia sebagai upah dosa yang diakibatkan oleh ketidaktaan manusia. Kematian dianggap sebagai hukuman Allah terhadap dosa. Alkitab berkata bahwa upah dosa adalah maut (Rm. 6:23). "Sama seperti dosa telah masuk ke dalam dunia oleh satu orang, dan oleh dosa itu juga maut" (Rm. 5:12a). Alkitab mengatakan bahwa Adam melanggar perintah Allah dan berdosa, sehingga kematian terjadi di dunia (Kej. 3:1-8). ${ }^{10}$ Karena dosa maka maut datang kepada masusia, sehingga dosa adalah alasan yang mendahului maut, dan sebagai tindak lanjutnya Allah mendatangkan maut. Oleh sebab itu dosa adalah murka Allah (Mzm. 90:7,11), penghukuman (Rm. 5:16), dan kutuk (Gal. 3:13). Kematian dianggap sebagai hukuman dari Allah (I Kor. 15:26). ${ }^{11}$ Alkitab juga mengajarkan bahwa kematian adalah rusaknya hubungan dengan Allah, pengusiran dari kehidupan bersama Allah dan tanda ancaman murka Allah. Karena itu kematian digambarkan

\footnotetext{
${ }^{9}$ Volkhard Scheuneman, Apa Kata Alkitab Tentang ..., 20

${ }^{10}$ Suh Sung Min, Injil dan Penyembahan ..., 241

${ }^{11}$ J.M.P. Batubara, Menghadapi Kematian, (Surabaya: Yakin, 1965), 23
} 
sebagai kerenggangan, keterpisahan, kepahitan (I Sam. 15:32), kengerian (Mzm. 55:4), dan penderitaan (Kis. 2:24).

Dalam konteks ini arti kematian tidak terbatas sebagai kematian fisik, melainkan dipakai juga untuk pengasihan dari Allah secara spiritual.

Hidup atau pun mati ada dalam tangan Tuhan. Kita dapat melihat kematian yang dalam Alkitab: Abraham dan Ishak meninggal setelah menikmati umur panjang (Kej. 25:8; 35:29). Yakub, Musa dan Elia mengalami kematian bukan sebagai hukuman Allah melainkan sebagai keputusan Allah. Jika seseorang mati dengan umur yang lanjut, kematian itu dianggap sebagai kematian natural. Oleh karena itu menurut pengertian Alkitabiah, kematian yang tidak berkaitan dengan hukuman dimengerti sebagai pemberian atau perwujudan keputusan Allah. ${ }^{12}$

Menurut Rasul Paulus, kematian bukan suatu titik akhir dalam kehidupan manusia. Paulus berpikir bahwa hari kematian adalah hari yang mengakhiri perjuangan di dunia dan hari untuk menerima mahkota kebenaran (II Tim. 4:7-8). Manusia mengakhiri kehidupan di dunia, dan orang Kristen yang berjuang dengan setia dalam peperangan iman akan mendapatkan mahkota. Melalui kematian, manusia mengalami perwujudan kehidupan dan anugerah yang dijanjikan dan diberikan Allah selama hidup di dunia.

Kematian manusia hanya dapat diatasi melalui Yesus Kristus. Yesus Kristus telah menanggung kematian di atas kayu salib, sebagai bagian dari karya penyelamatan Allah. Menurut Alkitab maut akan dihancurkan melalui ketaatan Yesus Kristus (I Kor. 15:2,26; Rm. 3:25; Gal. 3:13; 4:5; I Kor. 6:20; 7:23). Hukuman maut diatasi oleh Kristus. Allah mengatasi kuasa maut melalui Yesus Kristus, dan menyelamatkan manusia dari dosa dan maut.

\section{Pemakaman}

Upacara pemakaman dalam tradisi masyarakat Sumba Timur selalu diadakan secara besar-besaran. Upacara ini disertai dengan ritual penyembahan kepada nenek moyang serta roh orang mati tersebut. Kebiasaan masyarakat Sumba Timur dalam penyimpanan mayat sampai bertahun-tahun ini juga sangat bertentangan dengan iman Kristen. Praktek penyimpanan jenazah yang lama sebelum dikuburkan ini merupakan tindakan yang tidak memperlakukan orang yang mati dengan baik dan hormat. Tindakan ini hanya untuk kepentingan orang hidup dan bukan orang yang mati, yaitu untuk memperlihatkan status sosial dalam masyarakat.

Orang Kristen mempunyai tatacara penguburan sendiri yang berbeda dengan upacara penguburan orang marapu. Orang marapu memahami bahwa upacara penguburan menentukan masuk/tidaknya orang yang mati ke parangu marapu. Dalam pandangan iman Kristen, tatacara upacara penguburan, tidak menentukan masuk/tidaknya seorang ke dalam kerajaan sorga. Hal masuk/tidaknya seseorang ke dalam kerajaan sorga ditentukan oleh imannya kepada Yesus Kristus pada waktu orang itu masih hidup. Kehidupan orang yang percaya nantinya akan menerima kehidupan yang kekal di dalam kerajaan sorga, yaitu suatu negeri yang penuh dengan kesukaan dan kebahagiaan yang kekal.

\footnotetext{
${ }^{12}$ Suh Sung Min, Injil dan Penyembahan ..., 242
} 


\section{Hidup Sesudah Mati}

Dalam kepercayaan masyarakat Sumba Timur, setiap roh orang yang sudah meninggal tidak lenyap tetapi akan masuk ke dalam parai marapu. Dalam pandangan iman Kristen roh manusia akan terus hidup sesudah mati, dan tempat yang telah disediakan ada dua yaitu, pertama: tempat yang dihuni oleh bapa leluhur dan roh orang-orang kudus dan benar, yang disebut "pangkuan Abraham" (Luk. 16:22) atau " tempat makan semeja" dengan bapa leluhur (Mat. 8:11-12) atau "Firdaus" ( Luk. 23:43). Kedua, yaitu tempat yang disebut hades atau sheol, yaitu tempat yang dihuni oleh orang-orang durhaka atau jahat untuk menunggu hari penghakiman, akan tetapi di dalam hades atau sheol orang-orang jahat sudah mengalami siksaan (Luk. 16:24). ${ }^{13}$

Melalui perumpaan orang kaya dan Lazarus, Tuhan Yesus memberi dasar pengajaran tentang keadaan orang yang sudah meninggal, bahwa ada dunia kehidupan di balik kematian. Kemudian Tuhan Yesus memberi juga alamat ke mana seharusnya orang yang sudah meninggal. Kedua tempat yang sudah disediakan baik orang benar yang pergi ke pangkuan Abraham dan orang jahat yang pergi ke hades/sheol telah dipisahkan oleh jurang yang tak terseberangi. Hubungan antara orang yang masih hidup dengan orang yang telah meninggal telah terputus sejak peristiwa kematian itu. Sehingga orang yang hidup tidak bisa berkomunikasi ataupun memohon pertolongan dari orang yang sudah mati. Begitupun sebaliknya. ${ }^{14}$

\section{Metode Pendekatan Kontekstual}

Model-model atau metode pendekatan kontekstual ialah beberapa model penafsiran tentang berteologi dalam konteks yang didasarkan atas prinsip dokmatik tertentu. Model-model atau metode pendekatan ini memberikan gambaran umum tentang usaha berteologi dalam konteks yang pernah dibuat. Di samping itu, modelmodel atau metode tersebut menolong kita mengadakan evaluasi tentang sejauh mana suatu pendekatan teologi kontekstualisasi yang alkitabiah dapat dibuat. Ini juga akan menghindarkan kita dari kesalahan-kesalahan yang pernah dan akan timbul nanti. ${ }^{15}$ Model-model atau metode berkontekstualisasi dapat diuraikan dengan singkat sebagai berikut:

Pertama, model akomodasi (Kis. 17:28). Model akomodasi adalah sikap menghargai dan terbuka terhadap kebudayaan asli yang dilakukan dalam sikap, kelakuan, dengan pendekatan praktis dalam tugas misionaris, baik secara teologia maupun secara ilmiah. Obyek akomodasi adalah kehidupan budaya yang menyeluruh dari suatu bangsa, baik dari segi fisik, sosial, maupun ideal.

Yang kedua adalah model adaptasi. Perbedaan adaptasi dan akomodasi terletak pada cara pendekatannya. Model adaptasi tidak mengasimilasikan unsur budaya dalam mengekspresikan Injil, tetapi menggunakan bentuk dan ide budaya yang dikenal. Contoh yang jelas, Yohanes menggunakan ide logos untuk

\footnotetext{
${ }^{13}$ Suh Sung Min, Injil dan Penyembahan ..., 13

14 Pondsius Takaliuang, Antara Kuasa Gelap dan Kuasa Terang, (Batu: Literatur YPPII, 1979), 14

${ }^{15}$ Y. Tomatala, Teologia Kontekstualisasi, (Malang: Yayasan Penerbit Gandum Mas, 2001), 
menjelaskan kebenaran penjelmaan atau inkarnasi (Yoh. 1 ) dan Paulus menggunakan konsep rahasia (II Kor. 3:18). Tujuan adaptasi ialah mengekspresikan dan menterjemahkan Injil dalam istilah setempat (indigenous terms) sehingga menjadi relevan dalam situasi budaya tersebut. ${ }^{16}$

Yang ketiga adalah model prossesio, yaitu sikap yang menanggapi kebudayaan secara negatif. Proses prossesio terjadi melalui seleksi, penolakan, reinterpretasi dan rededikasi. Kelompok prossesio melihat kebudayaan sebagai suatu yang sudah rusak oleh dosa dan tidak ada kebaikan yang muncul dari dalamnya.

Yang keempat adalah model tranformatif. Allah itu di atas budaya, dan melalui budaya itu pula Allah menggunakan elemen-elemen kebudayaan untuk berinteraksi dengan manusia. Bila seorang dibaharui Allah, maka inti kebudayaannya juga dibaharui (II Kor. 5:17).

Yang kelima adalah model dialektik. Ini adalah interaksi dinamis antara teks dengan konteks. Konsep ini didukung oleh perkiraan yang kuat bahwa perubahan pasti ada dalam kebudayaan. Untuk setiap kurun waktu, perubahan itu terjadi secara dinamis. Dengan demikian gereja harus menggunakan peran kenabiannya untuk menganalisa, menginterpretasi dan menilai setiap keadaan. ${ }^{17}$

Dalam hal ini penulis akan menggunakan pendekatan yang ketiga dari teori Hiebert, yaitu mengumpulkan data kebudayaan dan mempelajari kebenaran Firman Tuhan tentang data-data ini, lalu mengevaluasi data dengan Firman Tuhan, kemudian menciptakan suatu kegiatan Kristen (berita) yang baru, atau dengan kata lain "berkontekstualisasi". Penulis akan menggunakan beberapa konsep kepercayaan dalam ritus-ritus upacara pemakaman yang berbau mistik untuk mengkomunikasikan Injil sesuai dengan kebenaran Firman Tuhan.

Konsep masyarakat Sumba Timur tentang kematian adalah: dewa atau marapu yang dipuja, marah karena pelanggaran tertentu. Kedua, karena kutukan. Ketiga karena roh-roh halus, kekuatan gaib di alam raya, akibat pelanggaran atau kelalaian manusia. Keempat karena adanya suanggi. Masyarakat Sumba Timur juga percaya bahwa kematian seseorang terjadi karena kehendak Alkhalik atau marapu.

Dalam hal kematian, harus dijelaskan bahwa kematian manusia adalah ditentukan oleh Sang Pencipta atau Tuhan Yesus. Kematian akan dialami semua orang, baik oleh orang yang baik maupun orang yang jahat, baik oleh orang percaya maupun orang yang tidak percaya kepada Kristus. Dengan demikian menjadi orang yang percaya tidaklah berarti bahwa tidak akan mengalami kematian. Orang percaya juga akan mati. Namun bagi orang percaya kematian itu bukanlah hal yang menakutkan, karena di balik kematian, mereka akan menerima kehidupan yang kekal di dalam sorga.

Masyarakat Sumba Timur percaya bahwa orang yang meninggal arwahnya akan mengembara, tetapi setelah dilakukan upacara pemakaman maka tubuhnya akan masuk ke dalam parai marapu, lalu menjadi dewa atau marapu. Konsep ini dapat dipakai untuk menjelaskan bahwa manusia terdiri dari tubuh dan jiwa, pada waktu seorang meninggal, jiwanya berpisah dengan tubuh. Tubuh kembali menjadi tanah karena berasal dari debu, sedangkan jiwa akan hidup terus karena berasal dari Tuhan Allah. Apabila orang percaya meninggal, tubuhnya masuk ke dalam tanah dan

\footnotetext{
${ }^{16}$ Ibib., 78

${ }^{17}$ Y. Tomatala, Teologia ..., 79
} 
hancur menjadi tanah, sedangkan jiwanya masuk ke sorga untuk menikmati pendahuluan keselamatan yang diberikan oleh Kristus. Seseorang yang tidak percaya, apabila ia meninggal, tubuhnya masuk ke dalam tanah, tetapi jiwanya mulai mengalami pendahuluan siksaan dan penderitaan. Pada hari kebangkitan, diberi tubuh yang baru dan dipersatukan kembali dengan jiwanya, dan semua orang yang telah meninggal, baik orang percaya dan tidak percaya akan bangkit dari antara orang mati, dan mereka akan menghadap pengadilan Kristus. Orang percaya akan memasuki kehidupan yang kekal di dalam kerajaan sorga, sedangkan orang yang tidak percaya akan masuk ke dalam hukuman kekal yaitu neraka. Di sorga, orang yang percaya akan bersekutu dengan Kristus. Di sana tidak ada lagi kesengsaraan dan air mata, serta orang tidak bekerja lagi. Di sana mereka senantiasa hidup memuliakan Tuhan Allah. Karena jiwa manusia itu pergi menghadap Tuhan Allah, maka orang Kristen tidak percaya bahwa setelah orang meninggal jiwanya masih tinggal di sekitar rumah atau di dalam kampung. Antara orang yang hidup maupun orang yang sudah mati tidak dapat saling berhubungan lagi.

Seseorang meninggal karena dipanggil oleh Tuhan Allah penciptanya melalui berbagai cara seperti sakit, jatuh dari pohon, ditangkap buaya, atau mungkin dibunuh orang. Kematian yang disebabkan oleh perbuatan suanggi tidak dipercayai oleh orang yang percaya kepada Yesus Kristus. Tidak ada seorang pun yang berkuasa atas hidupnya sendiri dan atas hidup orang lain, kecuali Tuhan Allah, karena hanya Tuhan Allah yang memegang nafas manusia. Oleh karena itu dalam kehidupan orang percaya tidak dikenal pembedaan antara mati dingin dan mati panas. Semua orang harus mendapat upacara penguburan yang sama tanpa membedakan cara mati, umur, dan status sosial karena semua orang merupakan gambar Allah.

Kebiasaan masyarakat Sumba Timur dalam penyimpanan jenazah yang lama sebelum dikuburkan, dapat dipakai sebagai jembatan untuk memberitakan bahwa penyimpanan jenazah yang lama merupakan tindakan yang tidak memperlakukan orang mati dengan tidak baik dan hormat. Tindakan ini hanya untuk kepentingan orang yang hidup dan bukan untuk orang yang mati, yaitu untuk memperlihatkan status sosial dalam masyarakat. Oleh karena itu, sebaiknya jenazah harus segera dikuburkan dan paling lama dua hari ditahan. Semua keluarga yang dapat dicapai mesti diberitahukan, dan upacara penguburan harus dilaksanakan pada waktunya, sekalipun tidak semua keluarga hadir. Penguburan yang cepat juga dimaksudkan untuk menghindari bau dari mayat dan mencegah kemungkinan menjalarnya suatu penyakit.

Jenazah harus dikenakan pakaian yang baik, dimandikan, rambutnya disisir, ditidurkan dan diletakkan dalam sebuah peti. Selama jenazah belum dikuburkan, jenazah dijaga supaya jangan ada binatang yang memakannya. Namun penjaganya bukanlah orang yang khusus seperti dalam agama marapu. Janasah dapat pula dikuburkan dalam kuburan batu atau tanah. Namun jika memakai kuburan batu, jenazah harus tetap dikuburkan cepat. Pohon bunga dapat ditanami di sekeliling kuburan, dan anggota keluarga tidak dilarang datang untuk menyiram bunga pada waktu-waktu tertentu. Perbuatan ini bukan dimaksudkan untuk menyembah dan memberikan makan kepada orang mati, tetapi sebagai ungkapan tanda cinta kasih keluarga pada si mati. Pemotongan hewan yang berlebihan selama jenazah belum dikuburkan dan pada saat upacara kematian harus dihindari. Hewan yang dipotong sebaiknya hanya cukup untuk menjamu para tamu yang datang dan tidak untuk 
dibuang-buang seolah-olah orang yang mati membawanya ke parai marapu. Orang percaya tidak mengenal dangangu (hewan bawaan orang yang mati) seperti orang marapu.

Orang percaya mempunyai tatacara kematian dan penguburan sendiri yang berbeda dengan upacaya kematian dan penguburan orang marapu. Orang Kristen mempunyai pemahaman yang berbeda mengenai tatacara tersebut. Jika orang marapu memahami bahwa upacara kematian dan penguburan menentukan masuk/tidaknya orang yang mati ke paraingu marapu, tetapi bagi orang percaya, tatacara upacara kematian dan penguburan tidak menentukan masuk/tidaknya seorang percaya ke dalam kerajaan sorga. Hal masuk/tidaknya seseorang ke dalam kerajaan sorga ditentukan oleh imannya kepada Yesus Kristus pada waktu orang itu masih hidup.

\section{Konsep tentang Allah}

Konsep orang Sumba Timur tentang Allah adalah ilah tertinggi atau marapu yang membentuk dan menganyam manusia, yang menciptakan langit dan menjadikan bumi. Ilah tertinggi ini selalu disembah oleh orang Sumba Timur untuk mendapatkan berkat dan keselamatan, dan jika ilah tertinggi ini tidak disembah maka ia akan mendatangkan kutuk dan malapetaka kepada masyarakat Sumba Timur. Jika melihat konsep kepercayaan Sumba Timur ini, maka ada beberapa unsur penting yang dapat dipakai sebagai batu loncatan untuk membawa kepercayaan lama dengan Injil Yesus Kristus. Konsep tersebut yaitu kepercayaan terhadap Anatala sebagai ilah tertinggi. Nama ini dipandang keramat. Oleh karena itu nama ini tidak boleh disebut sembarangan. Jika nama itu disebut sembarangan, maka orang itu akan tertimpa malapetaka. Orang Sumba Timur hanya mengungkapkan ilah tertinggi dengan ungkapan-ungkapan yang melukiskan hakekat, sifat dan tindakan-tindakan. Ilah ini merupakan ilah yang tertinggi dan tidak ada Ilah yang lebih tinggi dari padanya. Dialah yang menciptakan manusia, langit dan bumi. Ia menciptakan dengan tangan dan perkataannya dan dengan memakai bahan yaitu batu dan tanah liat. Segala sesuatu berasal dari padanya. Ia adalah Bapa dan Ibu dari segala sesuatu dan melebihi manusia. Ilah inilah yang memberikan tata dan norma dan kehidupan kepada manusia yang berupa adat istiadat yang harus ditaati oleh manusia dalam kehidupan bermasyarakat Sumba Timur. Ia merupakan maha pelihat dan tidak satu pun yang tidak dilihat dan tidak diketahuinya. Kesalahan dan kekeliruan manusia diperhatikannya dengan seksama dan ia mempunyai kasih yang besar dan maha pengampun. Kepercayaan ini telah membuat masyarakat Sumba Timur tunduk padanya. Kepercayaan ini dapat dipakai untuk menjelaskan tentang Allah di dalam Yesus Kristus sebagai pencipta dan penguasa segala sesuatu.

Dengan menggunakan pengertian-pengertian ungkapan daerah, penulis jelaskan bahwa Allah lebih berkuasa lagi dari marapu. Ia bukan saja menciptakan langit dan bumi, tetapi juga senantiasa memelihara, memerintah langit, bumi dan manusia. Alam semesta ini tidak oleh roh-roh atau pun oleh ilah-ilah seperti yang dipercayai oleh orang Sumba Timur. Nasib manusia tidak ditentukan oleh marapu, tetapi ditentukan oleh Tuhan Allah, yaitu Dia yang lebih berkuasa dari marapu. Tuhan Allah Mahabesar dan Mahakuasa. Kebesaran dan kekuasaan Tuhan Allah tidak dapat dibandingkan dengan kebesaran dan kekuasaan manusia termasuk 
didalamnya kekuasaan setan dan marapu. Tuhan Allah dapat melakukan apa yang dikehendaki-Nya. Tuhan Allah adalah Raja di atas segala Raja, dan kuasa-Nya tidak terhingga.

Dalam pemberitaan ini juga, penulis dapat menjelaskan tentang tempat kediaman Tuhan Allah. Tuhan Allah dan para malaekat berdiam di sorga. Sorga itu tidak kelihatan oleh mata fisik manusia. Sorga adalah langit di atas segala langit, yang disebut pula langit yang ketiga. Sorga itu adalah tempat yang tertinggi, yang termulia dan istana Allah, tetapi Tuhan Allah juga Mahahadir.

\section{Konsep Penciptaan}

Konsep penciptaan dalam masyarakat Sumba Timur dapat juga dipakai untuk mengkomunikasikan Injil kepada masyarakat Sumba Timur. Menurut kepercayaan Sumba Timur, manusia pertama yang ada di bumi ini tidak diperanakkan tetapi dibuat dan dianyam, diberi rupa dari gumpalan lumpur (tanah), kemudian dicelupkan ke dalam air untuk dibersihkan.

Alkitab mengatakan bahwa setelah Allah menciptakan langit dan bumi, tumbuh-tumbuhan dan binatang serta segala benda-benda yang lain, Allah menciptakan manusia (Kej. 1:26-27). Jadi manusia bukanlah dibuat dan dianyam dari gumpalan lumpur. Alkitab mencatat bahwa manusia diciptakan oleh Allah dari dua unsur yakni debu tanah dan roh yang dihembuskan oleh Allah. Melalui kemiripan pandangan ini, dapat dijelaskan kepada masyarakat Sumba Timur bahwa manusia adalah ciptaan Allah yang lebih tinggi dibanding dengan ciptaan Allah yang lain.

\section{SIMPULAN}

Tuhan menciptakan manusia dengan kemampuan berbudaya, termasuk masyarakat Sumba Timur. Namun di kecenderungan manusia, meekspresikan budaya mereka, tidak bisa dipisahkan dengan ekspresi spiritual mereka, karena manusia memang adalah makhluk spiritual, yang selalu berkerinduan untuk memiliki relasi dengan Sang Pencipta. Berbagai usaha dilakukan manusia, yang biasanya sarat dengan penyembahan berhala. Masyarakat Sumba Timur, juga sarat dengan penyembahan berhala, sejak seorang bayi berada di kandungan ibunya, hingga dia harus meninggalkan dunia ini. Namun bagi Masyarakat Sumba Timur yang sudah bertobat dan menjadi orang Kristen sebaliknya harus merefleksikan imannya yang relevan dan bermakna bagi masyarakat dan budaya Sumba Timur. Adapun rekomendasi-rekomendasi yang penulis berikan kepada Masyarakat Sumba Timur adalah sebagai berikut:

1) Harus menghindari ritus-ritus yang tidak sesuai dengan Firman Allah. Orang Kristen harus bersikap kritis terhadap budaya-budaya setempat yang merusak iman Kristen. Firman Tuhan harus menjadi tolak ukur etika.

2) Orang Kristen juga harus menjadi saksi yang hidup bagi masyarakat yang masih terlibat dalam upacara pemakaman. Misalnya dalam upacara pemakaman ini, pemukulan gong dengan irama duka bisa dilaksanakan oleh orang Kristen sebagai pertanda bahwa di tempat tersebut terjadi kematian. Tetapi pemukulan gong 
dengan irama pata lamba yang bertujuan untuk memanggil arwah leluhur (marapu) tidak boleh dilakukan oleh orang Kristen. Pemotongan hewan untuk menjamu makan para keluarga dan kerabat yang datang melayat untuk dimakan, orang Kristen dapat melakukannya. Tetapi pemotongan hewan yang tidak untuk dimakan, namun hanya sebagai simbol mendampingi arwah si mati, atau sebagai bekal si mati menuju alam baka tidak perlu dilakukan oleh orang Kristen, dan gereja harus melarang hal ini karena dari segi ekonomi hal tersebut sangat merugikan, dan dari segi teologis hanyalah menyia-nyiakan berkat Tuhan. Penyimpanan mayat yang terlalu lama dari segi kesehatan tidak menguntungkan, demikian juga dari segi ekonomi sangat merugikan karena membutuhkan biaya yang sangat besar. Sebaliknya seluruh keluarga berembuk dan menyelesaikan pertikaian, yang mungkin ada, dalam waktu yang tidak terlalu lama, agar si mati dapat dikubur cepat. Upacara padita waimata dapat dilakukan oleh orang Kristen dalam bentuk ibadah pengucapan syukur tutup duka. Upacara paludungu (menyampaikan arwah si mati) tidak perlu dilakukan oleh orang Kristen. Karena bagi orang Kristen setelah mati ia kembali berada dalam tangan Tuhan Sang Pencipta bukan menjadi marapu. 


\section{DAFTAR PUSTAKA}

Batubara, J.M.P.,

1965 Menghadapi Kematian. Surabaya: Yakin

Hiebert, Paul G.,

1985 Antropological Insights for Missionaries. Grand Rapids: Baker Book House

Peku Jawang, Umbu,

1987 Mozaik Pariwisata Nusa Tenggara Timur. Kupang: Dinas Pariwisata

Scheuneman, Volkhard,

1981 Apa Kata Alkitab Tentang Dunia Orang Mati. Batu: Literatur YPPII

Suh Sung Min,

2001 Injil dan Penyembahan Nenek Moyang. Yogyakarta: Medio Presondo

Takaliuang, Pondsius,

1979 Antara Kuasa Gelap dan Kuasa Terang. Batu: Literatur YPPII

Tomatala, Yakub,

2001 Teologia Kontekstualisasi. Malang: Yayasan Penerbit Gandum Mas

Tunggul, Nggodu,

2001 Aspek Budaya Sumba Timur. Kupang: Depertemen P dan K

Wellem, F.D,

2004 Injil dan Marapu. Jakarta: PT BPK Gunung Mulia 